\title{
Osmanlı Su Yollarının Sevk ve İdaresi
}

\author{
The Management and Administration of Ottoman Water \\ Conduits
}

\section{Mehdi İlhan*}

$\ddot{o} z$

Osmanlı'nın modern bir devlete yakışır şekilde her konuda idari bir sistem geliştirdikleri günümüze kadar ulaşan son derece düzenli bir arşivin mevcudiyetinde kendini göstermektedir. Fatih Sultan Mehmed'in su yollarının sevk ve idaresi için Su Nezareti kurduğ u bilinmektedir. Ancak Roma, Bizans ve Selçuklu döneminden kalma su yollarını ve şebekelerini kullanmaya devam eden ve yenilerini inşa eden Osmanlı'nın, Fatih Dönemi öncesinde de oturmuş bir yönetim sisteminden yoksun olduğu söylenemez. Bizans ve Selçuklu topraklarını devr alan Osmanlı'nın, devamlllık sürecinin kaçınılmaz bir gereği olarak, sabık yönetim sistemlerini de ne derece devr aldığ ve geliştirdiği çok geniş kapsamlı bir tartışmanın konusu olduğundan makalemizin dışında tutulmuştur. Arşiv kaynaklarına dayanan bu makalemizde bizim için önemli olan Osmanlı'nın su yolarını sevk ve idarede izledikleri yöntem, şehir ve kasabalarda halkın su ihtiyacını karşılamak için aldlkları önlemlerdir. Kilometrelerce uzaktaki suyun doğal kaynak ve barajlardan künkler ve su kemerleri yardımıyla havuzlara ve oradan sirasiyla maslak, maksem ve su terazilerine ulaştırılması ve akabinde şehir ve kasabalardaki sayısı cami, medrese, han, hamam, sebil, çeşme ve evlere tevzii şüphesiz oturmuş ve düzenli bir yönetim sistemi ile ancak gerçekleşebilirdi. Bu sistem çerçevesinde yeni su yollarının inşası veya eskilerinin tamiri için Su Nezareti'nce ve daha sonra ondokuzuncu yüzyllda oluşturulması üzerine Şehremaneti'nce bir keşif yapllır, gerekli insan gücü, para ve malzeme temin edilir ve işin bitiminde de varsa yolsuzlukları ve eksiklikleri ortaya çıkarmak için bir ikinci keşif daha yapılırdı.

* Profesör, Australian National University, Turkish Language and Culture, Centre for arab and Islamic Studies (The Middle East and Central Asia). 
Osmanlı'nın su yollarını koruma altına aldı̆̆l, tahribata sebep olanlar

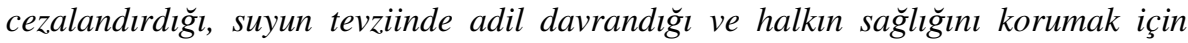
zaman zaman suyun tahlilini yaptırdığı Arşiv dokümanlarından anlaşılmaktadır.

Anahtar kelimeler: Osmanl, Su yolu, Su Nezareti, Şehremaneti

\section{Abstrract}

The Ottoman documents and their systematic arrangement and preservation in the Archives that have survived intact to our day is a good indication that the Ottomans had an excellent system of administration established in almost all their government offices. It is well known that Mehmed II had established the Su Nezareti, the Department of Water, under the Director of Waterworks that was responsible for the administration of water issues. However, this does not mean that the Ottomans, who had inherited the Byzantine and Seljuqid lands along with their water conduits and aqueducts as well as some of their administration, did not have an administrative office to solve the water problems. In this article, based on the documents from Ottoman archives, I will concentrate on Ottoman system of administering and managing water conduits as well as the procedures followed in supplying water to the towns and cities. There is no doubt carrying water from springs and dams by way of water conduits and aqueducts into reservoirs and from there to the water tanks (maslak), chambers (maksem) and balances (su terazileri) from where the water is distributed to the mosques, medreses, hans, public baths, fountains and houses is a considerable task that can only be achieved through a well established administration. The Ottomans, as part of this system, built new water conduits and aqueducts as well as maintaining the old ones. The Department of Water, besides being responsible from inspecting and supervising such tasks as these, supplied men and material as well as found money, and insured that everything ran smoothly. It is a fact, based on the documents, that the Ottomans had the water conduits and aqueducts guarded, brought to justice those who were responsible for damage, made sure the water was distributed to the public equally, and had the waters analyzed regularly to ensure that it was hygienic and suitable for drinking.

Keywords: Ottoman, water conduits, Director of Waterworks, Water Management, Şehremaneti.

\section{Yönetim}

Osmanlı şehirlerinin sokaklarında birçok çeşmelerin ve su kaynaklarının mevcudiyeti şüphesiz su yollarına verilen önemden kaynaklanmaktadır. Suyun şehir dışından getirilmesi sokaktaki ve evlerdeki çeşmelere ve suyun en çok kullanıldığı cami, mescid, medrese, han ve hamamlara tevzii son derece düzenli ve sürekli bir organizasyonu gerektirmektedir. Nitekim Osmanlılar su yollarının ve tesislerinin inşası, 
bakımı, onarımı ve suyun tevzii için Su Nezareti kurmuşlardır. Su Nezareti'nin yetki ve görevleri ondokuzuncu yüzyıl ortalarında Şehremaneti'ne devredilmiştir.

Fatih Sultan Mehmed devrinde kurulan Su Nezareti'nin başında bulunan Su Nazırı, başta cami, hamam ve çeşmeler olmak üzere şehir ve kasabalara düzenli ve devamlı su sağlanabilmesi için emrinde çalışan su yolcuları, keşif memurları, korucular, çavuşlar, bend muhafızları, neccarlar ve löğüncülerin görevlerini aksatmadan yürütmelerinden sorumluydu ${ }^{1}$. Suyun yönetimi ile ilgili bilgilerimiz Arşiv kaynakları ile Gülfettin Çelik'in makalesi ve Kazım Çeçen'in kitabına dayanmaktadır. Verilen bilgiler birbirlerini tamamlamakta ve kısmen örtüşmektedir. Çelik'in verdiği bilgiye göre "genel hususları iradeler ile düzenlenen İstanbul kaynak sularının ve su yollarının mülkiyeti, kullanımı ve işletilmesi ferağ ve intikali Haslar kadılığının vereceği hüccet ile hukukilik kazanmaktadır"2. Alınan karar ve uygulama safhası Su Nazırı tarafından başlatılıp Nezaretin en alt birimlerine kadar iner ve oradan ilgili hizmetin serbölüğüne kadar ulaşırdı. Serbölüğe ulaşan bu karar onun gözetiminde su yolcuları aracılığı ile uygulanırdı ${ }^{3}$. Su Nezareti ondokuzuncu yüzyılda idari yapıda yapılan değişikliklerden önce idari işlerin en üst organlarından biriydi. Büyük su tesislerinin tamiratında genellikle Ebniye-i Hassa Müdürü de görev alırdı. Su tesislerinin önemli bir kısmının vakıf olmalarından dolayı söz sahibi olan Vakıfların 1826' da Evkaf Nezareti'nin kurulması ile idari yetkileri daha da artmış ve vakıf sular merkezi bir yönetime kavuşmuştur. $\mathrm{Bu}$ arada 1854 yılında oluşturulan İstanbul Şehremaneti'nin ilk nizamnamesinde suların idaresi Şehremini'nin yetkisinin dışında tutulmuş ve dolayısıyla Evkaf Nezareti, Su Nezareti'nin yetkilerinin 1876 y1lında Şehremaneti'ne devredilmesine kadar geçen zaman içinde su tesislerinin inşa ve tamiratında önemli rol oynamıştır. Zira 18261854 yılları arasında su kaynaklarının tesbit edilip çıkarılması, tevzi ve işletilmesi Su Nezareti'nin, bakım ve tamirleri ise Evkaf Nezareti'nin sorumluluğunda idi. 1907 yılına kadar Şehremaneti bünyesinde yer alan Su Nezareti 1908 yılında yeniden Evkaf Nezareti'ne devredilmiş ve daha sonra da Miyah-1 Vakfiyye Müdüriyeti'ne dönüştürülmüştür ${ }^{4}$. Çeçen'e göre Su Nezareti uzun süre devam etmiş ve bir çok hizmetlerinin yanında çeşitli su

\footnotetext{
1“'Osmanlı Başkenti İstanbul'da Çeşmeler” http://www.osar.com/modules.php?name $=$ Encyclopedia\&op=content $\&$ tid=501201\&page $=3 \quad$ (erişim 30 Ekim 2007); Ayrica bakınız: "Fountains in Ottoman Istanbul" http://www.kultur.gov.tr/EN/BelgeGoster.aspx?17A16AE30572D313E603BF9486D4371DE E5931C025F918AA (erişim 14 Ocak 2008)

${ }^{2}$ Gülfettin Çelik, "İstanbul Kaynak Suları (Teşkilat ve İşleyişi ile)", XIV. Türk Tarih Kongresi (9-13 Eylül 2002), II/I, Ankara 2005, s. 791.

${ }^{3}$ G. Çelik,, a.g.m., s. 791-792.

${ }^{4}$ G. Çelik, a.g.m., s. 794-795.
} 
yolları haritaları yapılmıştır. Su Nezareti daha sonra Belediyenin bünyesinde Şehremaneti adı altında bir daireye dönüştürülmüsşür ${ }^{5}$. Vakıfların idaresinde Vakıf Sular Müdürlüğü altında varlıklarını koruyan vakıf sular da Sular İdaresi'nin emrine verilmiştir ${ }^{6}$. Diğer taraftan 1862 tarihli bir Arşiv dokümanına göre ise Dersaadet (İstanbul) ve Bilad-1 Selase'deki (Eyüp ve Çekmeceler ile Çatalca ve Silivri) ekserisi Evkaf'a ait su yollarının her türlü işlemleri Su Nazırı'nın idaresinde bulunmak üzere Evkaf Hazinesi'ne devredilmiştir ${ }^{7}$.

Ondokuzuncu yüzyıl Arşiv dokümanlarında verilen bilgilere göre ise başında Şehremini'nin bulunduğu Şehremaneti dairesi Enderun Hazinesi'nden alınan paralar ile yaptırılan çeşmelerin düzenli akmalarını ve gerektiğinde tamir edilmelerini sağladığı gibi evlerdeki çeşmelere devamlı su verilmesini temin eder, su yolları ile maslakların tamir işlerine bakardı. Su yolları ve çeşmelerin yapımı, tamiri, temizliği ve masraflarının ne şekilde tesviye olunacağına dair Evkaf-1 Hümayun Nezareti'nin iş'arı (yazısı) ve Şurayı Devlet Maliye Dairesi'nin mazbatası (kararnamesi) Şehremaneti'ne iletildikten sonra harekete geçilir ve gerekli işlemler yapılırdı ${ }^{8}$. Şehremini'nin emrinde çalışan su yolcu başı ve su yolcuları bu işlere bakarlar ve işlerin düzenli yürümesi için muhtelif semtlerde koğuşlarda yatar ve nöbet beklerlerdi. Su yolcu başı ve su yolcuları Sular İdaresi'nden aldıkları maaşlarına ilaveten kendi mıntıkalarında çeşmeleri olan evlerden ve hamamlardan aylık ve tamir bedelleri alırlardı ${ }^{9}$. Su Nezareti' nin yürürlükte olduğu dönemlerde de bu görevlerin pek değişik olduğu söylenemez. Gerek Mühimme Defterleri'nde yer alan onaltıncı yüzyıla ait hükümler gerekse Cevdet tasnifindeki onsekizinci yüzyıla ait dokumanlar bunu göstermektedir. Nitekim 1784'de Su Nazırlığı'na atanan Hacegandan Şakir Efendi'ye İstanbul'da cari bent suları hakkında bir dizi tedbirler alması emrolunmuştur $^{10}$. Her ne kadar Su Nezareti'nin kurulduğu Fatih dönemi

\footnotetext{
${ }^{5}$ Kazım Çeçen, İstanbul'da Osmanlı Devrindeki Su Tesisleri, İTÜ yayınları, İstanbul 1984, s.8; M. Kazım Çeçen, İstanbul'un Osmanlı Dönemi Suyolları, İstanbul: İSKİ yayınları 1999 [yeni bask1].

${ }^{6}$ Kazım Çeçen, a.g.e., s. 8.

7 İstanbul Başbakanlık Arşivi, Fon Kodu: A.\}MKT.MV, Gömlek No:30, Dosya No:147, Tarih: 6 Zi'lhicce 1278 (4.6.1862). Buradan sonra fon kodu, gömlek, dosya ve tarih gibi ibareler yazılmadan bu sıraya göre Arşiv dokümanları zikredilecektir. Mühimme Defteri de MD olarak kısaltılacaktır.

8 İstanbul Başbakanlık Arşivi, Cevdet Kataloğu, İrade Vakıf: i)519 (264), 4, 7 Rebi 'u'l-ahir 1311 (18.10.1893), ii) 1443 (531), 17, 25 Cemaziye'l-evvel 1312 (24.11.1894), iii) 2112 (1189), 2, 5 Şevval 1315 (27.2.1898); DH.UMVM 41, 100, 13 Cemaziye'l-ahir 1333 (28.4.1915).

${ }^{9}$ M. Zeki Pakalın, Osmanlı Tarih Deyimleri ve Terimleri Sözlüğü, İstanbul 1971, s. 289.

${ }^{10}$ Cevdet Kataloğu, Belediye no. 6587, tarih 1198 (1784).
} 
öncesi ${ }^{11}$ ve sonrası geçen yüzyıllar içinde suların üst düzey idaresinde köklü yönetim değişiklikleri yapılmışsa da su yollarının inşasında ve tamirinde, bakım ve tevziinde takip edilen yolun ve yöntemin ve alt düzey görevlerin değiştirildiği pek söylenemez. Daha da önemlisi bu yönetmeliklerin ve sularla ilgili kanunların Osmanlı Devleti'nin çöküşünden sonra bazı Orta Doğu ülkelerinde daha yakın zamanlara kadar uygulanmış olduğudur ${ }^{12}$.

\section{Tahribat}

Eşkıya, sel, deprem ve halkın bilinçsizce hareketleri su yollarında tıkanmaya ve tahribata yol açabiliyordu. Babıali su yolları 1902'de depremden ${ }^{13}$, Mekke'de Zubeyde su yolları 1796'da selden ve Kıbris adasında da yol, köprü ve su yolları 1860 'ta selden tahrip olmuşlardır ${ }^{14}$. Kandiye'de de eşkıya $1897^{\prime}$ de su mecralarını tahrip edip evleri yakmıştı ${ }^{15}$. Su yollarını tahrip edenler bir şekilde cezalandırılır ve verilen zarar tazmin ettirilirdi ${ }^{16}$.

Mühimme Defterleri'ndeki hükümlerde su yollarının ne şekilde ve kimler tarafından tahrip edildiklerine dair çeşitli örnekler bu konuyu daha bariz bir şekilde ortaya çıkarmaktadır. Bu hükümlerden anlaşıldığı kadarıyla Osmanlı yönetimince yağmur suları dahil suyun çıktığı mecra ve takip ettiği yollar ve kente ulaştırıldığında dağıtımı ve hatta kent içindeki yağmur suyunun aktığı mecralar ve mazğallar denetim altına alınmış ve dolayısıyla su mecraları ile mazğalların üzerlerine ev veya benzeri bina yapılması yasaklanmışıır ${ }^{17}$. Su yolları üzerine yapılan ve su yollarına zarar veren hane ve duvarlar yıktırılmıştır ${ }^{18}$. Dere ve çayların üzerine yapılan değirmenlerin arklarının taşması neticesinde çayırlara ve çevreye verdikleri zararlar, ve değirmenlere gelen kişilere ait hayvanların pisliklerinin değirmen arklarına karışması neticesinde çevreyi kirletmeleri tespit edilip gerekli kişilere uyarılar gönderilerek cezai müeyyideler uygulanmış ve gerekli önlemlerin

\footnotetext{
11 Türkiye'nin tarihi su yollarının bir özeti ve Efes, İzmir ve İstanbul gibi önemli kentlere uzaklardan suyu ulaştıran su yolları krokileri için bakınız: Ü. Öziş, A. Türkman ve Y. Özdemir, "Historical water Works in Turkey", Ninth International Water Technology Conference, IWTC9 2005, Sharm El-Sheikh, Egypt: http://www.angelfire.com/pro2/iwtc/2005_pdf/05-1.pdf (erişim 14 Ocak 2008)

12 Abraham M. Hirsch, "Water Legislation in the Middle East", The American Journal of Comparative Law, Vol. 8, No. 2 (Spring, 1959), s. 168.

${ }_{13}^{13}$ DH.MKT. 40, 540, 6 Rabi 'u'l-ahir 1320 (13.7.1902).

${ }^{14}$ HAT 10717, 205, 16 Cemaziye'l-ahir 1211 (17.12.1796); A.\}MKT.UM.. 61, 390, 22 Cemaziye'l-ahir $1276(16 / 1 / 1860)$

${ }^{15}$ Y..PRK.UM.. 59, 38, 24 Zi'lhicce 1314 (26.5.1897)

16 A.\}MKT.DV.. 3, 113, 20 Zi'lhicce 1273 (11.8.1857); A.\}MKT.UM.. 8, 24229 Şevval

1272 (3.7.1856).; A. \}MKT.MHM. 56, 380, 24 Zi'lhicce 1280 (31.5.1864)

${ }^{17}$ MD5 1262, 27 Şa‘ban 973 (19.3.1566); MD5, 1219, 20 Şa‘ban 973 (12..3.1566).

${ }^{18}$ MD19, 376, 21 Safer 980 (3.7.1572).
} 
alınması mahalli yöneticilerden istenmiştir ${ }^{19}$. Bu konuda Bursa kadısına gönderilen hüküm kayda değer:

'Gökdere'de bulunan değirmenin suyunun yola akarak çevreye zarar verdiği yolundaki şikayetin araştırılması neticesinde, sözkonusu değirmene gelen insanlara ait at, katır vs. hayvanların pislikleri değirmen suyunun aktığı arkın kenarına boşaltıldığı için değirmen suyunun çevreyi kirlettiği tesbit edildiği bildirildiğinden, bu durumun önüne geçilmesi ve kimsenin kanuna aykırı iş yapmasına izin verilmemesi $^{20}$.

Su yolları üzerinde veya civarında çift sürülmesi, ziraat yapılması, bağ ve bahçe dikilmesi tahribata yol açtığından her yıl bazı su yollarının tamiri gerekmiş ve dolayısıyla zararın önlenmesi için su yollarının geçtiği yerlerin her iki tarafında en az dörder arşın ve üstünde de birer $\operatorname{arşın}^{21}$ yerin hali (boş) kalması emir buyrulmuş ve bu emre uymayanların şer'i mahkeme kararıyla cezalandırılmaları ve verilen zararın tazmin ettirilmesi istenmiștir ${ }^{22}$. Su kaynaklarının, mahzenlerinin ve çeşmelerin suistimal edilmeleri, gayri kanuni olarak zapt veya tahrip edilmeleri engellenmiş kanuna aykırı hareket edenlerin cezalandırılmaları yoluna gidilmiştir ${ }^{23}$. Bu konuda Mühimme defterlerinden bir kaç örnek kayda değer sanırım:

'İstanbul Kadısı'na ve Su yolu Nazırı'na hüküm:

İstanbul'da at sakaları Kırkçeşme ve Ayasofya ve At Meydanı ve Kuyumcular Karhanesi çeşmelerinden su almak mu'tad iken bütün mahallata yayılıp halkın su almasına mani' oldukları ve halk lüleli çeşmelerin lülesini kırıp suyu boşa akıttıkları ve hamamcılar su yolu

\footnotetext{
${ }^{19}$ MD5, 542, 27 Rabi 'u'l-ahir 973 (21.11.1565); MD5, 1143, 14 Şa‘ban 973 (6.3.1566).

${ }^{20}$ MD5, 694, Ğurre-i Cemaziye'l-ahir 973 (24.12.1565).

${ }^{21} \mathrm{Bir}$ arşın $68 \mathrm{~cm}$ olduğuna göre su yolunun her bir tarafında $2.72 \mathrm{~cm}$. boş yer bırakılması istenmektedir.

${ }^{22}$ Bu konuda 25 Şevval 979 tarihli hüküm aynen şöyledir:

'Haslar Kadısı' na hüküm ki:

Halen Su yolu Nazırı olan Müteferrika Hasan gelip "merhum ve ceddim Sultan Mehmed Han -tabe serrahu-'nın Yenihisar'da olan Cami 'i'nin ve çeşmelerinin aşağara başında su yollarının üstünde bazı kimesneler çift sürüp ve bağ bağçe dikip ol sebep ile su yolları her yıl meremmete muhtaç olup harap olup su yolları geçtiği yerlerde iki canibinde dörder arşun ve üstünde birer arşun yer hali kalmak gerektir [ki] zarar müterettib olmaya deyu bildirmeğin" buyurdum ki:

Vusul buldukta bu babda mukayyed olup anun gibi su yolları geçtiği yerlerde çift sürüp ve bağ ve bahçe dikip su yollarına zarar-1 şer'ileri olanların vaki' olan zararların şer'le def' u ref eyleyip şer'i şerife muhalif kimesneye iş ettirmeyesin.' MD12, 1019, 25 Şevval 979 (11.3.1572); Aynı konu için bakınız MD12, 1086, 8 Zi'l-ka'de 979 (23.3.1572); MD12, 536, 22 Zi'l-hicce 978 (17.5.1571).

${ }^{23}$ MD5, 870, 5 Receb 973 (26.1.1566).
} 
kapılarını ve bacalarını açıp suyu istedikleri yere sevkettikleri bildirilmekle bütün bunların men edilmesi ve dinlemeyenlerin bildirilmesi hakkında' ${ }^{24}$.

'Medine-i Münevvere Kadısı'na ve Şeyhü'l-Harem'e:

Medine-i Münevvere'de Bab-1 Rahmet'de ki Kayıtbay Vakfı'na ait su mahzeninin bazı kişiler tarafından işğal edildiği bildirildiğinden durum arzedildiği gibi ise işğalcilerin buradan çıkarılmaları ve bundan sonra da kimsenin vakfın şartına aykırı iş yapmasına izin verilmemesi, ${ }^{25}$.

'Şam Beylerbeyi ve Kadısı ile Kudüs-1 Şerif Kadısı'na:

Sabık Kudüs-1 Şerif Kadısı Carullah'ın üç yüz yıldır kullanılan sebili yıkıp yerine kahvehane yaptırdığı, kaza gelirlerini mukata'a olarak naiblere, Halilü'r-Rahman Evkafını da kendi adamlarına verdiği, ayrıca daha bir çok yolsuzluklarının olduğu; bunun dışında Kudüs-1 Şerif mahkemesinin muhzır başısının da halka zulmettiği yolunda re'ayadan bazıları şikayette bulunduklarından, adı geçen Carullah'ın şimdiki görevi olan Menzile Kadılığı'ndan azlolunduğu; kendisi oraya geldiğinde yukarıdaki iddia ve şikayetlerden dolayı teftiş olunması ve üzerine sabit olan suçların yazılıp bildirilmesi ${ }^{26}$.

Su mecralarına bilinçsizce sed çekildiğinde geri tepen su tahribata yol açtı̆̆ından Medine-i Münevvere ile Cürf adlı menzil arasında sed çekmek suretiyle bahçelerini sulamak isteyen şahıslar Mısır muhafazasında olan Vezir Ahmed Paşa'ya ve Medine-i Münevvere Kadısı'na ve Şeyhü'lHaremi'ne gönderilen bir hüküm ile bu uygulamadan men edilmişler ve bağ ve bahçelerini sulamak için koğa ve dolap ile su çekmeleri emr olunmuştur ${ }^{27}$.

\section{Keșif}

Su yolu tamir veya inşaatına başlamadan önce merkezden gelen bir emir üzerine bölgede su yolcuları başının direktifinde işten anlayanlara bir keşif yaptırılır ve bu keşif merkeze gönderilirdi. Bu keşifte gereğine göre su yolunun nerede yapılacağı suyun alınacağ arasında ne kadar mesafe olduğu, inşaatın ne kadar zaman alacağı, ne kadar malzeme gerektiği, kaç akçaya ihtiyaç olduğu, başkalarının hakkına tecavüz edilip edilmediği, su kaynağı veya su yolu bir köyün sınırları içinde ise köy halkının rızasının alınıp alınmadığı ve herhangi bir vakfa zararı olup

${ }^{24}$ MD19, 324, 13 Safer 980 (3.7.1572).

${ }^{25}$ MD5, 1770, 14 Zi'l-ka'de 973 (2.6.1566).

${ }^{26}$ MD5, 1248, 25 Şa ‘ban 973 (17.3.1566)

${ }^{27}$ MD82, 93 [274], 21 Cemaziye'l-ahir 1026 (26.6.1617). 
olmadı $\breve{g} ı$ belirtilirdi ${ }^{28}$. Edirne kadısına yazılan bir hükümden Cisr-i Mustafa Paşa'da yapılan bir imarete suyun getirilmesi için girişimde bulunulmuş ve rapor yazılmış ancak yukarıda belirtilen şartlar olumlu olmadığından sonunda suyun Meriç nehrinden dolap ile alınmasına karar verilmiştir. Sadece bu iş için altmış bin akçeye ihtiyaç duyulduğu şayanı dikkattir ${ }^{29}$. Su yollarının ve aslını muhafaza etmek şartıyla çeşme ve sebillerin tamiri ${ }^{30}$ için de aynı şekilde keşif şartlarının yerine getirilmesi gerekiyordu ${ }^{31}$.

Keşif bilhassa işten anlayan bir mühendisin veya üst düzey bir memurun başkanlığında mimar ve su yolcuları tarafından yapılarak bir deftere işlenirdi. Tamir veya inşaat masraflarını içeren bu keşif defteri incelenmek üzere bir komisyona takdim edilir ve karara bağlanırd $1^{32}$. Herhangi bir yolsuzluğu gidermek için gerektiğinde su yollarına sarf olunan meblağın meydana çıkarılması için de keşif ve gerekli tahkikat yapılırdı ${ }^{33}$. Ayrıca tamirin bitiminde ortaya çıkan masrafın onaylanması, suyun vezn ve ayarının yeniden tespit edilmesi için bir keşif daha yapılırdı. Mahallinde yapılan bu keşif mahkemenin görevlendirdiği şahıs, kamu görevlileri ile su yolcuları ve su nazırından oluşan bir komisyon tarafından tarafgirliği bertaraf etmek için ahalinin huzurunda yapılırdı ${ }^{34}$.

İstanbul şüphesiz su konusuna önem verilen kentlerin başında gelirdi. Tamiri gereken su yollarının tespit edilip keşfin yapılması için özel bir görevli tayin edilir ve bu görevli yanında su nazırı, bina emini, Haremeyn-i Şerifeyn evkaf müfettişi, sadrazam müfettişi ve evkaf mütevellileri gibi üst düzey görevlilileri yanına alarak keşfe çıkardı. Örneğin 1798 tarihli bir fermana göre Sultan Selim III Saray-1 Atik, Saray-1 Cedid, Ayasofya ile Selatin-i İzam ve katmalara akan Kırkçeşme ve Halkalı sularının su yollarının, bentlerinin ve katmalarının tamire ve bakıma muhtaç olanlarının tesbiti ve keşfi için Divan-1 Hümayun topçular katibini görevlendirmiştir. Yukarıda zikredilen görevlileri de yanına alan topçular katibi istenilen keşfi yaparak neticeleri bir deftere kaydetmiştir. Bu gibi defterlere maliyetin paylaşımını sağlayabilmek için suların nerelere tevzi edildiği ve özel katmaların sahipleri de kaydolunurdu ${ }^{35}$.

${ }^{28}$ MD3, 871, 26 Cemaziye'l-ahir 967 (24.3.1560); MD6, 726, 14 Recep 972 (15.2.1565).

${ }^{29}$ MD3, 871, 26 Cemaziye'l-ahir 967 (24.3.1560).

${ }^{30}$ Cevdet Kataloğu, İrade Vakıf, 1011 (2491), 1, 2 Cemaziye'l-evvel 1324 (24.6.1906).

${ }^{31}$ MD3, 159, 23 Şevval 966 (29.7.1559).

${ }^{32}$ HAT 29307, 597, 29 Zi'lhicce 1234 (19.10.1819); A.\}MKT.NZD 58, 295, 18 Rabi 'u'l-ahir $1276(14.11 .1859)$.

${ }^{33}$ A. \}MKT.NZD. 3 , 159, 1 Zi'lhicce 1271 (15.8.1855).

${ }^{34}$ G. Çelik, a.g.m., s. 805, 818.

${ }^{35}$ G. Çelik, a.g.m., s. 806. 


\section{Para Temini}

Su yollarının tamir ve inşası mali açıdan masraflı bir iş olup masraflar başta Devletin bütçesinden ${ }^{36}$ ve yerine göre bizzat Padişah'ın kendisi, Evkaf1 Hümayun, Belediye, hizmet götürülen müessese veya dükkan sahipleri, hayır sahibi biri veya halkın kendisi tarafından karşılanıyordu. Tophane su yollarının tamiri ile Gelibolu su yollarının inşası Padişah ${ }^{37}$, Kudüs su yollarının tamiri Şam Valisi Yusuf Paşa ${ }^{38}$, Çeşme kazasına tabi Yeni nahiyesine içme suyu getirilmesi Belediye ${ }^{39}$, İstanbul Çarşıkapı'daki hanlara mahsus lağımların tamiri dükkan sahipleri ${ }^{40}$, Kırkçeşme su yoluna karışan lağımların tamiri halk ${ }^{41}$ tarafından karşılanmış ve "Usturumca kazasında bozulan su yollarının mütevellisi tarafından veyahut Müslüman ve gayriMüslim ahali tarafından tamir ettirilmesi” istenmiştir ${ }^{42}$. Vakıflara ait su yollarının tamirat masrafları ilgili vakıf tarafından karşılanır ve birden fazla vakfın müşterek kullandığı suların masrafları da kendilerine tevzi edilen suyun miktarına göre maliyet aralarında paylaşılırdı. Vakıfların birçoğu bilhassa ondokuzuncu asırda mali sıkıntı çektiklerinden vakıf suyu satarak veya kiraya vererek tamirat masrafını karşılama yoluna giderlerdi. Vakıf suyun tamir bedeli karşılığında satışı bazen mülkiyet bazen de tasarruf hakkının devri şeklinde olurdu. Sik rastlanmayan bir diğer uygulama da kiraya verilen vakıf su yolunun ileride ortaya çıkacak tamirat bedelinin kiracıya yüklenmesiydi. Herhangi bir nedenle vakıflar tamirat masrafını ödemediklerinde $\mathrm{Su}$ Nezareti harcanan tamirat masrafını vakfın mal mevcudundan re'sen tahsil ederdi ${ }^{43}$. Bazen de tahrip olan vakıf su yollarının tamiri vakıf malının araştırılmasına ve üzerlerinde vakıf malı olanlardan tahsil edilmesine bir vesile olabiliyordu. Aşağıdaki hüküm bunun tipik bir örneğidir:

\footnotetext{
${ }^{36}$ Devletin bütçesinden karşılanan masraflar genelde en yakın merkezden temin edilirdi. Örneğin Mısır Beylerbeyine yazılan bir hükümde Mekke suyolu inşasını yürüten İbrahim'e mühürlü temessük karş1lığında istediği kadar para ve levazımat verilmiş ve verilenlerin bir defteri tutularak İstanbul'a (Südde-i Sa‘adete) gönderilmiştir [MD5, 1188, 15 Şa ‘ban 973 (7 Mart 1566)]. Diğer bir hükümde ise Arafat'a gelecek suyolu inşaatı için Misır Beylerbeyi'nden istenen "kırk bin altının yirmibeş bini surre mahsulünden, onbeş bini de Mısır'dan" temin edilmiştir [MD5, 1495, 8 Şevval 973 (28.4.1566)].

${ }^{37}$ HAT 14604, 255, 29 Zi'lhicce 1213 (3.6.1799); HAT 33160, 680, 3 Zi'lhicce 1254 (17.2.1839).

${ }^{38}$ HAT 34651/P, 728, 21 Zilka'de 1224 (28.12.1809); HAT 34651/L, 728, 29 Zi'lhicce 1224 ((4.2.1810); HAT 19647/I, 344, 11 Muharrem 1225 (16.2.1810).

${ }^{39}$ DH.MKT. 61, 1507, 28 Şa'ban 1305 (10.5.1888).

${ }^{40}$ A. \}MKT.NZD. 31, 59, 29 Zi'lhicce $1268(14.10 .1852)$

${ }^{41}$ A. \}MKT.NZD. 39, 65, 4 Safer 1269 (17.11.1852).

${ }_{42}$ MKT.UM. 44, 491, 7 Safer 1278 (14.8.1861).

${ }^{43}$ G. Çelik, a.g.m., s. 804-806, 824.
} 
'Tuna Defterdarı'na ve Hezerğrad Kadısı'na hüküm ki:

Müteveffa İbarahim Paşa Evkafı'nın mütevelli-i kebiri olan Seyyid Yahya Südde-i Sa'adetim'e 'arz-1 hal sunup; "müteveffa-i mezbur İbrahim Paşa'nın Hezarğrad' da vaki ' cami '-i șerifinin su yolları harap olup vakfın ta'mir(i) ve termim etmeğe müsa'adesi olmayıp vakf-1 mezburun sabıka mütevellileri olan Mustafa ve Çeribaşı oğlu 'Abdullah Çavuş'un muhasebeleri görülmeyip bu ana dek üzerlerinde ziyade mal-1 vakf olmağın yerli yerinde muhasebeleri görülüp zimmetlerinde zuhur eden mal-1 vakf ile mütevellisi ma'rifetiyle su yolları ta "mir ü termim olunmak" babında emr-i şerifim rica eylediği ecilden buyurdum ki:

Vusul buldukda, husus-i mezbure muakayyed olup mütevelli-i mezburan 'Abdullah Çavuş ve Mustafa' yı şer'i şerife ihzar [ve] hala olan mütevelli ma'rifetiyle beraber edip dahi mütevelli oldukları eyyamdan bir def'a şer'le görülmeyen muhasebelerin müfredat defteri mucebince yerli yerinde hakk üzere görüp dahi zimmetlerinde zuhur eden mal-i mevkufi șer'le tahsil edip vakf-1 mezbur mütevellisine teslim eyleyesiz ki ol vakıf akça ile su yolların tamir ü termim ettiresüz. Amma mal-i vakf zayi` olmakdan ziyade hazer eyleyesiz." ${ }^{44}$

Bazen de ahali veya köyün ileri gelenlerinden biri bazı tekaliflerden muaf tutulmasına karşın su yolunun tamirini üstlenebiliyordu. Bu konudaki bir Mühimme hükmü hem böyle bir kişinin başvurusu hem de dolaylı yoldan kendisine yapılan haksızlığı merkeze şikayet etmesi ve de köy halkının sıkıntısının giderilmesi açısından önemine binaen burada aktarmayı uygun buldum:

'Nevesin Kadısı' na hüküm ki:

Mektup gönderüp; "kaza-i mezbure tabi' Vatniçe nam karyede Kuklet (?) nam mahallede vaki' Yasterfiye (?) demekle ma'ruf tarik-i 'amm üzerinde olan sudan ayende ve revende ve mahall-i mezbure ahalisi müntefi“ olup lakin ol suyun yolları harab olmağla su gelmeyüp viran olmağla ebna-i sebil ve mahalle-i mezbure ahalisi muzayaka üzre olmağla ta'mir ü termimi mühimmatdan olmağla yine mahalle-i mezbure ahalisinden Bekir oğlu 'Ali nam kimesne için, min ba'd ol sunun yolların ta'mir ü termim eylemeğe kadir olmağla rızasıyla ta 'mir eylemeğe mukirr ve mu'terif olmağla "hizmeti mukabelesinde min-ba'd mir-liva ve kethüdaları ve sübaşıları ve sayir ademleri ve ehl-i 'örf tayifesi evine konmayıp ve müft ü meccanen yem ü yemek ve tavuk ve koyun u kuzu ve yağ u bal ve sayir me'kulatın ve

${ }^{44}$ MD82, 121 [248], 15 Şevval 1026 (16.10.1617). 
selamiyye ve na'l-baha ve kaftan-baha ve bunun emsali tekalif-i şakka namına bir akça ve bir habbesi alınmamak" babında emr-i şerifim ricasına arzeylediğin ecilden buyurdum ki:

Vusul buldukda, bu babda onat mukayyed olup dahi mezbur 'Ali madam ki ol suyun yolların ta'mir ü termim edip bir vechile hizmetde kusuru olmaya, min ba'd mezburun evine mir-liva ve kethuda ve sübaşıların ve ademlerin ve sayir ehl-i 'örf tayifesin kondurmayıp ve müft ü meccanen yem ve yemeklerin ve tavuk ve koyun u kuzu ve yağ u bal ve arpa ve sayir me'kulatın ve selamiyye namına ve na'l-baha ve kaftan-baha ve bi'l-cümle bunun emsali tekalif-i şakka namına bir akça ve bir habbe aldırmayıp men' ve def' eyleyesin; 'inad üzre olanları yazup arzeyleyesin. ${ }^{45}$

\section{Malzeme Temini}

Su yollarının inşasında ve tamirinde demir boru, kurşun, filtre makinesi gibi çeşitli malzemeler kullanılırdı. $\mathrm{Bu}$ malzemenin genellikle gayr-i müslimlerden satın alındığı ve bazen de Avrupa'dan ithal edildiği dokümanlardan anlaşılmaktadır. Yıldız Sarayı'na akan Taksim Su Yolu'nun tamiri için gerekli borular Şehremaneti'nce Avrupa'dan getirtilmiş ${ }^{46}$ ve ayrıca İstanbul su yolları için gerekli malzemeden sadece su boruları gümrük resminden muaf tutulmuşlardır ${ }^{47}$. Fransalı Arlan'a Beşiktaş su yolları masrafından dolayı olan alacağına karşılık kendisine sergi pusulası verilmiştii ${ }^{48}$.

$\mathrm{Su}$ yollarının yapım veya tamirinde kullanılan kireç, kereste ${ }^{49}$ ve su yolunda çalışanların buğday ve diğer yiyecek ihtiyaçları genellikle en yakın merkezden temin edilir ve bina eminine teslim edilirdi ${ }^{50}$. İbrahim adında birinin yönetiminde Arafat dağından Mekke'ye getirtilecek su yolu inşaatı için gerekli malzeme ve buğday Misır'dan getirtilmekte idi ${ }^{51}$. Bu arada Mekke şerifinden de gerekli yardımı esirgememesi istenmiş ve istek en güzel

\footnotetext{
${ }^{45}$ MD82, 257 [116], 26 Rab1 'u'l-ahir 1027 (22.4.1618).

${ }^{46}$ DH.MKT 11, 1529, 1 Zilka'de 1305 (3.9.1888)

${ }^{47}$ MV. 34, 95, 1 Muharrem 1316 (22.5.1898)

${ }^{48}$ HR.MKT. 4, 100, 28 Rabi 'u'l-ahir 1271 (18.1.1855).

${ }^{49}$ MD3, 314, 8 Zi'lhicce 966 (11.9.1559); MD6, 1337, 4 Zi'lhicce 972 (3.7.1565). Örneğin İstanbul'da su yolunun tamiri için gerekli kerestenin İstanbul havalisindeki ormanlardan temin edilmesinin yanı sıra Büyükdere'deki ağaçlar sadece Miri suyolu için tahsis edilmişlerdi [MD14, 406, $27 \mathrm{Zi}^{\prime} \mathrm{lka}^{\prime} \mathrm{de} 979$ (11.4.1572)].

${ }^{50}$ Cevdet Kataloğu, Belediye kısmı, no. 2316, 29 Muharrem 1260 (19.2.1844).

51 MD6, 435, 29 Rebi'u'l-ahir 972 (4.12.1564); MD6, 440, 7 Cemaziye'l-ula 972 (11.12.1564); MD6, 448, Gurre-i Cemaziye'l-ula 972 (5.12.1564) (Bu hükümden anlaşıldığına göre Mekke'de ki su yolu inşaatı bir yıldır devam etmektedir).
} 
şekilde yerine getirildiğinden sekiz ay sonra kendisine teşekkür edilmiştir ${ }^{52}$. Bir ara gerekli para ihtiyacı hacı kafilesi hareket etmiş bulunduğundan dolayı Misır'dan temin edilemeyince Cidde mahsulünden yirmi beș bin florin bu da mümkün olmadığı takdirde Mekke ve Cidde'de bulunan Misır tüccarlarından temessük verilmek suretiyle gereken paranın temin edilmesi emir buyrulmuştur ${ }^{53}$. Ayrıca İstanbul'dan Mısır Beylerbeyiliği aracılığıyla mezkur İbrahim'e gönderilen gizli evraktan çalışmanın sağlıklı bir şekilde devamı için merkezin bir denetim mekanizması görevini yüklendiğini de anliyoruz $^{54}$.

\section{Görevlendirme}

Su yollarının yapımında bir çok kişiler görevlendirilirdi. Kadılara gönderilen bir hükümle sıraları gelen müsellem ${ }^{55}$, yörük, yeniçeri taifelerinden ve hatta re'ayadan adamların görevlendirilmeleri emir buyrulurdu. Ayrica orducular yani sanatkarlar da bunlara katılırlardı ${ }^{56}$. Başlarında da dergah-1 mu'alla çavuşlarından biri, kendi subaşıları ve beyleri bulunurdu. Su yolu hizmetine tayin olunduklarına dair hükümleri yazılır ve muhzir katibine verilirdi ${ }^{57}$. Ayrıca gerektiğinde kadılar aracılığıyla bunlara hükümler gönderilir ve direktifler verilirdi ${ }^{5}$. Görevlendirilenlerin bir defteri tutulur ve ne zaman göreve başladıkları sancaktaki defterdarlar tarafından İstanbul'a yazılı olarak bildirilirdi ${ }^{59}$. Nöbetlü olarak görevlendirilen bu kişilerin sıraları geldiklerinde zamanında ve eksiksiz olarak yerlerine varmaları ve iş başı yapmaları subaşıları ve beyleri tarafından temin edilir ve herhangi bir ihmal affedilmezdi ${ }^{60}$. Ayrıca su yolunda hizmet eden re'ayanın ellerine maliye tarafından mu'afname verilir ve rahatsız edilmemelerine bilhassa özen gösterilirdi ${ }^{61}$. Yurdun her tarafından benna ve neccar gibi sanatkarların da su yolu inşaatında çalıştırıldıklarını görüyoruz ${ }^{62}$. Selden tahrip olan İstanbul su yollarının tamiri gerektiğinde Edirne kadısından yaşlıları içermeyen benna ve neccarların deftere yazılıp gönderilmeleri

52 MD6, 456, Selh-i Rebi 'u'l-ahir 972 (5.12.1564); MD6, 1329, Gurre-i Zi'l-hicce 972 (30.6.1565).

${ }^{53}$ MD6, 1169, 19 Şevval 972 (20.5.1565).

${ }^{54}$ MD6, 457, Selh-i Rebi'u'l-ahir 972 (5.12.1564).

${ }^{55}$ MD6, 69, 18 Muharrem 972 (26.8.1564).

${ }^{56}$ MD6, 789, 27 Receb 972 (28.2.1565).

${ }^{57}$ MD6, 599, 10 Cemaziye'l-ahir 972 (13.1.1565).

${ }^{58}$ MD3, 314, 8 Zi'lhicce 966; MD3, 843, 10 Cemaziye'l-ahir 967 (8.3.1560).

${ }^{59}$ MD3, 77, 25 Ramazan 966 (1.7.1559).

${ }^{60}$ MD3, 843, 10 Cemaziye'l-ahir 967 (8.3.1560); MD6, 69, 18 Muharrem 972 (26.8.1564).

${ }^{61} \mathrm{MD} 3,1538,26$ Zi'lhicce 967 (17.9.1560).

${ }^{62}$ MD6, 77, 18 Muharrem 972 (26.8.1564). 
istenmiştir ${ }^{63}$. Ayraca bu iş için Mısır'dan gerekli taş ve ağacın taşınması için de yüz elli nefer arka hamalı getirtilmiştir ${ }^{64}$.

$\mathrm{Su}$ yolu hizmetinde, Zaptiye Nezareti'ne kayitlı 1861 tarihli bir dokumana göre, yanaşma, hizmetkar ve korucu gibi kişiler de çalıştırılırlardı. Bunların yoklamaları yapılır kefilsiz ve tezkeresiz olanlar kefalete bağlanılırlardı ${ }^{65}$. Ayrıca su yollarının tamir ve inşasında köylüler istihdam edilir ve mukabilinde hane-i avarız ve tekalif-i 'örfiyeden mu'af tutulurlard ${ }^{66}$.

$\mathrm{Su}$ yolu hizmetinde bulunanlara gerekli yardımın yapılması, yeteri kadar hisar ereni, inşaat ve taş ustası gibi çalışanların alet ve edevat ile birlikte temin edilmeleri veya hizmet yerine gönderilmeleri için kadı, dizdar ve sancak beylerine hükümler gönderilirdi ${ }^{67}$. Su yolu hizmetine mûtaallik muhasebelerin defterleri tutularak nazır ve katiple İstanbul'a gönderilirdi ${ }^{68}$.

$\mathrm{Su}$ yolu hizmetinde çalışacak işçiler genelde en yakın merkezden temin edilirlerdi. Örneğin Mekke'ye ve Arafat'a getirilecek su için taşçı ve demirci gibi işçiler Mısır, Şam ve Halep gibi yakın merkezlerden, löğüncü ve su yolcuları gibi görevliler ise merkezden Misır üzeri Mekke'ye gönderilmişlerdir ${ }^{69}$. Ancak Mekke'ye gönderilen taşçı ve demirci gibi işçilerin hac mevsimi sonunda hacılara katılarak kaçmaları ve bazılarının himaye edilmeleri dikkatimizi çekmektedir. Mühimme hükümlerinde bu gibilerinin geri gönderilmeleri ve himaye edilmemeleri emredilmektedir ${ }^{70}$.

\section{Ödeme, Emniyet ve Ödüllendirme}

İstanbul'da Su Nezareti, Şehremaneti kurulup ve 1870 yılında su işlerini üstlenene kadar, bünyesindeki görevlilerin maş̧larını karşılamakla yükümlüydü. Gerektiğinde de ödemeler Evkaf Hazinesi'nden karşılanırd1 ${ }^{71}$. Ayrıca yaya ve müsellem ve sipahiyan gibi askeri ocaklardan su yolu hizmetine gönderilenlerin de 'ulufe ve nafakaları Mühimme hükümlerinden anlaşıldığı kadarıyla ocakları tarafından veya gittikleri yerde karşılanır ve görevlerinin bitiminde serbest bırakılırlardı. İşin durumuna göre hizmet sürelerinin uzaması mümkün olmakla beraber kırk gün ila altı aylık bir

\footnotetext{
${ }^{63}$ MD6, 548, 27 Cemaziye'l-ula 972 (31.12.1564).

${ }^{64}$ MD6, 555, 26 Cemaziye'l-ula 972 (30.12.1564).

${ }^{65}$ ZB 95, 1, 10 Ramazan 1277 (22.3.1861).

${ }^{66}$ HAT 10130, 199, 29 Zi'lhicce 1205 (29.8.1791); HAT 15140, 29 Zi'lhicce 1218 (10.4.1804); HAT 17042, 284, 29 Zi'lhicce 1223 (15.2.1809)

${ }^{67}$ MD5, 113 ve 114, 4 Şa'ban 973 (24.2.1566).

${ }^{68}$ MD5, 112, 4 Şa‘ban 973 (24.2.1566).

${ }^{69}$ MD5, 257, 24 Safer 973 (20.9.1565); MD5, 261, 27 Safer 973 (23.9.1565).

${ }^{70}$ MD5, 1493, 8 Şevval 973 (28.4.1566) MD5, 1495, 8 Şevval 973 (28.4.1566).

${ }^{71}$ G. Çelik, a.g.m., s. 796.
} 
zaman dilimi konulurdu ${ }^{72}$. Göreve gönderilenlerin ayrıca zad ve zevadeleri ile bargirleri temin edilirdi. Bilhassa yeniçerilerin büyük bir ihtimalle çalışmalarında başarılı olmalarından dolayı kapuya alındıklarını yani terfi ettirildiklerini $^{73}$ ve daha iyi çalışmalarını sağlamak ve teşvik etmek için ödüllendirildiklerini görüyoruz ${ }^{74}$. 1564-65 yıllarında Arafat dağından Mekke'ye su getirmekle görevli İbrahim ve Mısır kullarının maaşları arttırılmış ve bazılarına da kul gediği verilmesi için Mısır Beylerbeyi'ne hüküm yazılmıştır ${ }^{75}$. Bilhassa Mekke'ye su getirilmesi işine son derece önem verilmiş ve dolayısyla gerekli malzemenin temini için yeterince gayret sarfedilmenin yanısıra su yolu hizmetinde çalışanlarından bazılarına gedik ve terakki tevcih edilmesi emrolunmuştur ${ }^{76}$. Ayrıca Misır sancak beylerinden olup Mekke su yollarının inşasını yürüten İbrahim Bey vefat ettiğinde oğullarına ait 'ulufenin su yolu yapımında yararlık gösterenlere dağıtılmasını talep etmiş ve bu talebi yerine getirilerek hak edenlerin isimleri bir deftere yazılıp Mısır Beylerbeyi'ne gönderilmiştir ${ }^{77}$. Yine Mekke-i Mükerreme'de Dergah-1 Mu'alla müteferrikalarından Hüseyin vefat ettiğinde geride bıraktığı mülk evi varisi olmadığından miri karhaneye ilhak edilerek su yollarına nazır olanlara mesken olarak tahsis edilmiştir ${ }^{78}$. Aynı şekilde Mekke'de Arafat su yollarına nazır tayin edilen ve günlük otuz akça 'ulufeye mutasarrıf olan Dergah-1 Mu'alla müteferrikalarından Süleyman'ın bu

${ }^{72}$ MD3, 94, 28 Ramazan 966 (4.7.1559); MD3, 843, 10 Cemaziye'l-ahir 967 (8.3.1560); MD82, 92 [279], 21 Cemaziye'l-ahir 1026 (26.6.1617).

${ }^{73}$ MD3, 1581, 10 Muharrem 968 (1.10.1560); MD6, 1292, 19 Zi'l-ka'de 972 (18.6.1565); MD6, 1300, 24 Zi'l-ka'de 972 (23.6.1565).

${ }^{74}$ MD6, 267, 15 Rabi ‘u'l-evvel 972 (21.10.1564): Bu hükmün önemine binaen burada olduğu gibi yazmada fayda mulahaza ettim:

" Yazild1.

Yeniçeri Ağasına hüküm ki:

Haliya senünle su yoli hizmetinde bulunan kullarım hakkında mezid-i atifet-i husrevanım zuhura getürüp yayabaşılardan neferinin dördi bölüğe ve dördi ze'amete ve acemi oğlanları yayabaşılarından bir neferi bölüğe ve iki neferi ze'amete ve bölükbaşılarımdan üç neferi bölüğge ve dört neferi timara ve atlu zağarcılarından üç neferi bölüğe ve iki neferi timara ve atlu sekbanlarından üç neferi bölüğe ve üç neferi timara ve sekbanlar bölükbaşılarından iki neferi bölüğe ve üç neferi timara ve solaklardan onüçi bölüğe ve onikisi timara ve yeniçerilerinden yiğirmibeş neferi bölüğe -ki, nısfı sipahi ve nısfı silahdar ola- ve yiğirmibeş neferi dahi timara ve iki yüz akçe dahi dört yüz buçuk akçe olur müstahik olan yeniçeri kullarıma tevzi' içun ta'yin idüp ve yüz nefer acemi oğlanı kapuya alınmasın emredüp buyurdum ki: Vech ü münasip gördüğün üzre kullarımdan zikrolunan mikdarın bölüğe ve timara ta'yin edüp ve ihsan olunan akçayı müstahik olanlara tevzi' eyleyup 'ulufelu acemi oğlanlarında ol mikdarın kapuya çıkarup kullarıma gereği gibi istimalet virüp hizmete terğip ettiresin. Şöyle bilesin."

${ }^{75}$ MD6, 450 \& 451, Gurre-i Cemaziye'l-evvel 972.

${ }^{76}$ MD5, 391, 22 Rebi 'u'l-lahir 973 (17.10.1565)

${ }^{77}$ MD5, 607 ve 608, 4 Cemaziye'l-evvel 973 (27.11.1565).

${ }^{78}$ MD82, 90 [277], 21 Cemaziye'l-ahir 1026 (26.6.1617) 
görevde bulunduğu sürece müteferrikalık 'ulufesinin Mısır Hazinesi'nden ödenmesi için Mısır muhafazasında olan Vezir Ahmed Paşa'ya bir hüküm gönderilmiştir $^{79}$. Temmuz 1818 tarihli bir takrire göre de Su yolcular ocağının nizamnamesi değişmiş ve su nazırı, kethüda ve katibin maaşlarına zam yapılmıştır ${ }^{80}$.

Ondokuzuncu yüzyıl dokümanlarından su yolu çalışanlarının başarılarından dolayı ödüllendirildikleri anlaşılmaktadır. Örneğin Liyej şehri Su Yolları Şirket-i Umumiyesi'nden Mösyö Bend ile Mösyö Martin Kağıthane membaından su getirilmesi esnasında yaptıkları başarılarından dolayı Osmanlı Nişanı ile taltif edilmişlerdir ${ }^{81}$. Aynı şekilde Medine-i Münevvere su yollarının açılmasında yararlık gösteren bazı şahıslara Osmanlı Nişanı verilmiştir ${ }^{82}$.

Zaman zaman su yolu çalışanları rahatsız edilir hatta çatışmalara maruz kalırlardı. Kandiye su yolunun tamiri esnasında eşkıya ile İslam ahali arasında çarpışma olmuş ve bölgede ileri gelenler huzurun sağlanması için girişimlerde bulunmuşlardır ${ }^{83}$. Mevlevihane Şeyhi Mehmed Said su yolcu Celiloğlu Ahmed'i yaraladığından şeyhlikten azledilerek cezalandırılmıştır ${ }^{84}$.

\section{Görevi İhmal ve Yolsuzluk}

Ödül ve teşvike rağmen su yolu hizmeti görevine gitmeyenler de oluyordu. Bu gibiler her ne pahasina olursa olsun aranıp bulunuyor ve şiddetle cezalandırılıp küreğe konuluyorlard ${ }^{85}$. Bazen su yolu için tahsis edilen paranın tamamı harcanmaz ve yolsuzluklar olurdu. Kudüs'e

\footnotetext{
${ }^{79}$ MD82, 91 [278], 21 Cemaziye'l-ahir 1026 (26.6.1617).

${ }^{80}$ Cevdet Kataloğu, Belediye 3-ç/1, 4532 Ramazan 1233 (5.7.1818).

${ }^{81}$ Y..PRK.TKM. 60, 46, 11 Safer 1321 (9.5.1903); Y..PRK.TKM. 67, 23, 22 Safer 1321 (20.5.1903)

${ }^{82}$ DH.KMS. 47, 26, 20 Zi' lhicce 1332 (9.11.1914)

${ }^{83}$ Y..PRK.MYD. 24, 19, 19 Zi'lhicce 1314 (21.5.1897).

${ }^{84}$ A. \}MKT.UM.. 30, 324, 2 Muharrem 1275 (12.8.1858).

${ }^{85}$ MD3, 50, 18 Ramazan 966 (24.6.1559); MD6, 1014, 13 Ramazan 972 (14.4.1565). Bu konuda bu son hüküm bizi oldukça aydınlatmaktadır:

'Yazıld1.

Ademine verildi. Fi 13 Ramazan sene 972

Selanik Yörükleri bulunan yerlerün kadılarına hüküm ki:

Haliya Selanik Yörükleri Subaşısı Hüsrev dame mecdühü Südde-i Sa'adetime adem gönderüp "subaşılığına mute'allik olup taht-1 kazanuzda sakin olan Yörükler ferman-1 şerifümle su yolu hizmetine ta'yin olundukda varmayup evlerinde kalup tenbih ü te'kid olundukda dahi “inad edüp ihmal ü müsahele itdüklerin” bildürmeğün buyurdum ki: Hükm-i şerifimle müşarün ileyhin ademleri vardıkda, her birinüz taht-ı kazanızda sakin olup muma ileyhun subaşılığına mute 'allik yörükler emr-i şerifümle su yolu hizmetine ta'yin olundukda asla te'hir ü tevakkuf etdirmeyüp ve gaybet edenleri onbaşılarına ve müştereklerine teklif edüp buldurup ta'yin olunan hidemata sürüp çıkarup ihmal etdirmiyesüz. Şöyle ki, ferman olunan hizmete çıkmak tenbih olundukdan sonra varmayup inad edüp evlerinde kalanı kayd u bend edüp Südde-i Sa 'adetime gönderesin ki küreğe konula. Şöyle bilesiz.'
} 
getirilmesi ferman olunan Azub nam su yolu için Haleb Hazinesi'nden altı bin beş yüz altın tahsis edilmiş, ancak o sırada Kudüs-i Şerif ve Gazze sancaklarında Havass-1 Hümayun Emini olan Mustafa Kethüda bu paradan bin altınını teslim edip, gerisi daha sonra kendisinden talep edildiğinde tamamını teslim ettiğini iddia etmesi üzerine müteveffa mütevelli Turgut'un yetiminden talep edilmiştir. Ancak Kudüs-i Şerif Beği Rıdvan'ın bizzat İstanbul'da mezkur 5500 sikke florinin Mültezim Mustafa'nın zimmetinde olduğunu söylemesi üzerine Halep Defterdarı Derviş Çelebi'ye gönderilen hükümde konunun araştırılması ve paranın kimin zimmetinde olduğunun tespit edilmesi emir buyrulmuştur ${ }^{86}$.

Ondokuzuncu yüzyılın sonlarında su yollarının inşaat ve tamiri şirketlere mukavele karşılığında verilmeye başlanmış ve bu şirketlerin mukavele şartlarına göre hareket edip etmedikleri sıkı takip altına alınmıştır. Örneğin Terkos Su Şirketi'nin taahhüt ettiği maddelerin uygulanıp uygulanmadığg tahkik edilmiştir ${ }^{87}$.

\section{Önlem, Uyarı ve Koruma}

$\mathrm{Su}$ yolu yapılırken ve yapıldıktan sonra dikkat edilmesi gereken hususlar vardi. Sokak ve caddelerde su yolu inşa ve tamir edilirken insanların ve hayvanların emniyeti göz önünde bulundurulur ve meydana gelecek muhtemel kazaları önlemek için çukurlar kapatılır ve gerekli yerlere işaretler konurdu ${ }^{88}$. Su yolu inşaatının bitiminde de açılma merasimi yapılır ve halkın memnuniyet ve teşekkürü ile nutuklar okunurdu ${ }^{89}$. Su yollarının başka binalara örneğin bir kervansaraya zarar vermemesine ${ }^{90}$ ve komşu ülkelerin sınırlarına tecavüz etmemeğe çok dikkat edilirdi ${ }^{91}$. Diğer taraftan su yollarının yapımı sırasında bir çok arazinin istimlak edilmesini ve yol üzerindeki meyve ağaçlarının kesilmesini de üzüntüyle karşılamak gerekir ${ }^{92}$.

Su yolları yapıldıktan sonra da muhafazalarına ehemmiyet verilir ve herhangi bir zarar ulaşması engellenirdi. Örneğin Yahudilerin mezarlıklarına yakın olmasından dolayı su yolu üzerinde ölülerini gömmeleri su yoluna zarar vermiş ve hüküm gereğince bunların ölüleri çıkarılıp başka yerlere gömülmekle kalınmamış verilen zarar tazmin ettirilmiştir ${ }^{93}$. Hatta su yoluna zararı önlemek için bazen vakıfların bostanlarının sulanması dahi

\footnotetext{
${ }^{86}$ MD6, 49, 17 Muharrem 972 (25.8.1564).

${ }^{87}$ Y..PRK.HR.. 85, 33, 27 Safer 1321 (25.5.1903)

${ }^{88}$ DH.UMVM. 12, 105, 28 safer $1336(13,12,1917)$

${ }^{89}$ Y..PRK.UM:. 17, 24, 22 Şaban 1309 (22.3.1892).

${ }^{90}$ MD6, 997, Ğurre-i Şevval 972 (2.5.1565).

${ }^{91}$ MD6, 700, 6 Recep 972; MD6, 706, 7 Receb 972

${ }^{92}$ MD6, 718, 12 Recep 972.

${ }^{93}$ MD6, 309, 26 Rebi ‘u’l-evvel 972.
} 
engellenmiştir ${ }^{94}$. Su yollarının bir adamın içine sığıp hapishaneden kaçacak kadar geniş olduklarını da dokümanlardan anlıyoruz ${ }^{95}$.

$\mathrm{Bu}$ kadar güçlükler ile tamamlanabilen bir sistemin giderlerini karşılamak için tabii ki suyu kullananlardan ve arazilerini sulayanlardan su parası alınırd ${ }^{96}$. Su parası ödeyenlerin haklarını korumak için de suyun tevzi ve tasarrufuna dikkat edilir ve herhangi bir nedenle haksız olarak tasarrufa müdahale edenler engellenir, eşirraya karşı su yolları korunur ve emniyetleri sağlanırdı ${ }^{97}$. Bu bağlamda bilhassa İstanbul'a su ulaştırılmasında kullanılan Terkos ve Feriköy arasındaki ana su yolu ile Alibey deresi üzerindeki köprünün eşirradan korunması için gerekli tedbirler alınmıştı ${ }^{98}$. Su yollarının tahribine herhangi bir nedenle sebebiyet veren şirket, iş yeri veya hanelerden zarar tespit edilerek tazmin edilirdi. Su yolunun geçtiği yerlerin üzerine ve çevresine kişinin mülk arsası olsa dahi su mecralarına zarar verecek şekilde bina yapılmasına müsaade edilmezdi ${ }^{99}$. Örneğin Üsküdar Selamsız'da Duhanizade Veliyüddin'in kendi arsası üzerine ev yapmasına müsaade edilmemiştir ${ }^{100}$. Ermenilerin Üsküdar'da satın aldıkları bağda baca ve çirkap (atık) kuyuları açmaları engellenmiştir ${ }^{101}$. Su yollarının sıkı bir şekilde korunması da gerekiyordu. Koçi Bey Sultan III. Murad (1574-1595) döneminde sayıları 36153'ü bulan 'Ulufeli kul taifeleri arasında 54 nefer su

${ }^{94}$ MD6, 777, 27 Receb 972.

${ }^{95}$ MD6, 1411, 17 Zi'lhicce 972 (16.7.1565).

${ }^{96}$ MD6, 54, 28 Muharrem 972 (5.9.1564):

'Yazıldi.

Mütevelliye verildi.

Şam Beylerbeğisine ve Sayda Kadısına Hüküm ki :

Müşarün ileyh mütevelli kazaya defterin sunup, 'Evkaf-1 mezbureden nefs-i Sayda ve Kenise ve Haliv nam mezre'alara getürilen su, te'addülen her bostana ve her eve cari olmağın vakf içün emr mucebince birer mikdar akçe ta'yin olunup defter-i Hazine'ye gönderilmeğin ol defter mucebince Nerduban Mehmed nam za'im ve sabıka Emin olan Ali ve Nasıru'd-din ibn-i Kutayş nam kimesneler zimmetlerinde zikr olunan bostanların suyundan ve zeyt bekasından hayli mal-i vakf baki kalup edasında te'allul ederler' deyu i'lam etdügi ecilden buyurdum ki: Dergah-1 Mu'allam korucularından Abdi varup vusul buldukda, husamayı ihzar idup onat vechile teftiş edüp göresiz; şimdiye değin zikrolunan sudan intifa' idenlerden şer'le ve kanun ile vakfa nesne alınugelmiş ise eger zeyt bahasından ve eger sudan her birinün zimmetlerinde ne mikdar baki kalmış ise ba'de's-sübut hükmidüp bi-kusur alıvirup vakf içun mütevelli-i mezkura zabtitdüresüz. Onat vechile mukayyed olup mal-i vakfdan kimesne üzerinde bir akçe ve bir habbe komayasiz'.

${ }^{97}$ A.\}MKT.MVL. 36, 42, 27 Recep 1267 (28.5.1851)

${ }^{98}$ DH.TMIK.S.. 35, 48, 29 Cemaziye'l-ahir 1321 (22.9.1903).

${ }^{99}$ DH.UMVM 27, 101, 20 Cemaziye'l-ahir 1337 (23.3.1919).

${ }^{100}$ DH.MKT. 40, 5, 1 Muharrem 1312 (5.7.1894); A.\}MKT.UM.. 8, 242, 29 Şevval 1272

(3.7.1856); A.\}MKT.MHM. 56, 380, 24 Zi'lhicce 1280 (31.5.1864).

${ }^{101}$ HAT 27434, 554, 29 Zi’lhicce 1244 (2.7.1829). 
yolcu ve korucu siralar ve 40 nefer dağ korucularının su yollarını beklediklerini yazar ${ }^{102}$.

$\mathrm{Su}$ yollarının ve tesislerinin korunması için para vakıfları oluşturulmuş, tesislerin yakınında bulunan bazı köylere "su yolu kurası" adı altında su yollarının korunması, bakım ve tamiri için görevler ihdas edilmiş ve karşılığında su yolu nazırına ödedikleri bad-ı heva, cürm ü cinayet ve resm-i 'arusane'nin haricindeki bir çok veya tüm vergilerden muaf tutulmuşlardır. İstanbul'da Taksim (Kağıthane), Belgrad ve diğer su yollarını koruma ve bakımına tahsis edilen ve daha önce iki olan köy sayısı onaltıncı asrın ikinci yarısında onikiye çıkarılmıştır. Bu köyler bazı vergilerden muafiyetleri karşılığında mezkur su yollarının bakım ve onarımı için ırgat yetiştirir ve gereken hizmeti verirlerdi ${ }^{103}$.

\section{Tahlil, Tevzi ve Zayi}

Halka içilebilir temiz suyun tevzii için zaman zaman su yollarından ve çeşmelerden alınan örneklerin tahlili yapılır, sıhhi olmayan su yolu veya çeşme temizlenme işlemi bitene kadar kapatılır ve bu arada mahallenin su ihtiyacı bir başka su yolundan veya çeşmeden giderilirdi ${ }^{104}$. Ayrıca suyun yerinde kullanılmasına, zayi ve israf edilmemesine dikkat edilirdi. Nerede ne miktar su gerektiği belirlenir ve ölçümler yapılır, ne şekilde tevzi edileceğine kararlar verilir ve ona göre mahallelerdeki evlere, cami. mescid, medrese, han, çarşı ve hamamlara dağıtım yapılır ve belirli yerlerde çeşmeler bina edilirdi ${ }^{105}$. Tabi bu dağıtımda dahi belli kurallar göz önünde bulundurulurdu. Örneğin Kudüs-i Şerif'de Sahratu'l-lahi Şerife evkafından Hazret-i Davud hamamının kuyu suyu ile ancak iki ay işleyebildiği ve diğer zamanlar mu'attal olduğundan vakfa zarar geldiği belirtilerek hamama su verilmesi için müracaatta bulunulmuştur. Kudüs-i Şerif beğine ve kadısına yazılan hükümden anlaşıldığına göre şehirdeki halkın suyuna zarar gelmemesi ve ne miktar su gerektiği belirlenip İstanbul'a bildirildikten sonra hamama ancak çok verilmeyip bir miktar su verilmesi karara bağlanmıştır ${ }^{106}$. Devletin ileri gelen görevlilerinin evlerine dahi belirli miktarda su verilirdi. Südde-i Sa'adet Kapucılarıbaşı ve Mirahur Ferhad İstanbul'da Kırkçeşme yakınındaki evine mezkur çeşmeden su almak için müracaatta bulunduğunda bir kamıştan ziyade su verilmemesi emrolunmuştur ${ }^{107}$. İstanbul Kadısı'na yazılan bir hüküm ile İkinci Kapucubaşı Mehmed'in İstanbul'da Piri Paşa

\footnotetext{
${ }^{102}$ Göriceli Koçi Bey, Koçi Bey Risalesi, yay. Yılmaz Kurt, Ankara 1994, s. 30-31, 52, 23-24.

${ }^{103}$ G. Çelik, a.g.m., s. 800-801.

${ }^{104}$ DH.EUM.THR. 17, 23, 15 Muharrem 1328 (25.1.1910).

${ }^{105}$ MD3, 23, 16 Ramazan 966; MD6, 273, 17 Rebi'u'l-evvel 972.

${ }^{106}$ MD6, 113, 4 Safer 972 (11.9.1564).

${ }^{107}$ MD6, 1325, Gurre-i Zi'lhicce 972 (30.6.1565).
} 
namındaki evine verilen su bir kamış olarak tahdid edilmiştir ${ }^{108}$. Aynı şekilde Vezir Mehmed Paşa'nın İstanbul Cebeci' de harefttiği suyun "canib-i şer'-i şerifden ta'yin olunan kimesneler ve ehl-i vukuf ile" yapılan keşfin neticesinde üç masura olduğu takdir olunduktan ve ne kadarının Sultan Süleyman Camii'ne akan su yoluna ve vakfına ilhak edilmesi gerektiği tesbit edildikten sonra geri kalanının vezirin kendi hanesine ve istediği diğer yerlere tevzi edilmesine karar verilmiştir ${ }^{109}$. Yine Dergah-1 Mu'alla Çavuşlarından Hasan İstanbul'a tabi Ayvadlı köyü sınırı dahilinde kendi malı ile harefeylediği suyu Sultan Süleyman Han'ın getirdiği suya ilhak edip vezn [ü] ayarını talep ettiğinde iki masura su olduğu tespit edilmiş ve üçte birinin Kasımpaşa'da bina eylediği çeşmesi ile Gedik Paşa'daki sebilhanesinin kuyusuna akıtılması takdir olunmuştur ${ }^{110}$. Bilhassa memba sularının zayi olmaması için mevcut bentler zaman zaman yükseltilmiş, yenileri yapılmış ve mahallelerde yeter görüldüğü kadar çeşmelerin yapılmasına özen gösterilmiştir ${ }^{111}$. Suyun tevziine ve zayi olmamasına Osmanlılardan önce de özen gösterildiğini ortaya koyan Kanuni Sultan Süleyman'ın kanunnamesi bu konuda söylediklerimizi şöyle özetlemektedir:

'Ve Konya bağlarının her dönümüne otuz akçe alınur imiş. Evailde mirablığı mukata'aya alan kimesne bağları suvarıcak şehirlü ittifakiyle emin adamlar çıkarup mirablık resmi alınur imiş. Sonra su kısmetine amil kendü mütevelli olup resimde asıl kanundan tecavüz edermiş. Ve hem bağların suvaracak vaktinde tedbirler var imiş. Ziyade resm veren kişiye vaktinde nevbeti gelmeden nevbet virilür imiş. Su az olduğu yillarda sonra hadis olan bağlara zarar olacak iken kadim bağlara ki, şirb anlarındır, anlara zarar olurmuş. Eyle olsa yine evvelki gibi şehirlü ittifakiyle emin Müslümanlar mütevelli nasb olunup suyu kismet etmek emr olundu. Ta ki, kimesneye zarar olmaya. Sonra hadis olan bida' ref' olundu.

Ve mirablığı amele alan kimesne, ba'zı kimesnelere bostan ekdürüp sülüs-i hasılın kendü alup sülüsanın bostancı almak kavl eylermiş. Bu sebeple bağlarun hakk-1 şirbi zayi' olurmuş. Karaman oğlu zamanında mezkur suyla heman üç bostan suvarırlar imiş; birisi dizdar ve birisi hatun ve birisi dahi Merhum Mevlana Celaleddin Hazretlerinin türbe-i mutahharası mesalihi içün ekilürmiş. Bakisi bağlara ve çeşmelere ve hamamlara sarf olunur imiş. Ve Cem Sultan

${ }^{108}$ MD5, 49, 10 Muharrem 973 (7.8.1565).

${ }^{109}$ MD82, 51 [316], 22 Zi'lhicce 1026 (21.12.1617).

${ }^{110}$ MD82, 370 [2], 10 Zi'l-ka 'de 1027 (29.10.1618).

${ }^{111}$ Cevdet, İrade vakıf 1, 1148 (2078), 12-19 Cemaziye'l-evvel 1321 (6-13.8.1903). 
kal'adan taşra bir köşk yapub asıl sudan köşküne gelmeğe bir mikdar su alup köşk havalisinde bağ dahi edermiş. Sonra ol bahane ile köşke nazır olan kimesneler asıl sudan çok su ayırup yolda bostanlar ihdas edüp harc ederler imiş. Müslümanların hamamlarına hayli noksan ve zarar olur imiş ${ }^{112}$.

\section{İstanbul'a Su Tevzii ve Sıkıntılar}

Suyun en fazla tüketildiği ve bazen su sıkıntısının çekildiği şehirlerin başında şüphesiz İstanbul gelirdi ve dolayısıyla İstanbul'a son derece özen gösterilmiş, özel komisyonlar kurulmuş, detaylı krokileri ve haritaları çizilmiş ve hatta İstanbul Terkos İdaresi'ndeki su yollarında meydana gelebilecek herhangi bir tahribat veya zarardan anında haber alınabilmesi için mezkur su yolları boyunca İstanbul Su Şirketi tarafından telefon hattı tesis edilmiştir ${ }^{113}$. Bütün bunlara rağmen su ihtiyacını gidermede güçlük çekilmiş ve bazı mahallelerde halk susuzluktan muzdarip olmuştur ${ }^{114}$. Zaman zaman bendlerin (su kemerlerinin) temizlenip tamir edilmeleri ve tamirat yapılırken veya geç kalınmasından dolayı su sıkıntısının giderilmesi için başka membalardan çeşmelere su getirilmesi gerekirdi. Bilhassa Osmanlının son zamanlarında para sıkıntısından dolayı İstanbul'un bir çok semtlerinde yeterince hizmet verilememiş ve onarımların yapılması güçleşmeye başlamıştı. Örneğin bir dokümana göre "Dersaadet ve Bilad-1 Selase'ye ait bentler, tatlı su kuyularıyla katmaların ve su yollarının uzun süredir tamir ve temizliği yapılmadığından eskisi kadar su toplanamadığı ve yarısından çoğu yollarda zayi olduğu, su yolcuları fahiş fiyatla su satarak fakir fukarayı gözetmediklerinden Şehremanetinde bir komisyon kurularak 1slahat yapılması" $" 115$ yoluna gidilmiştir. Bir diğer dokümana göre İstanbul'un bazı mahalleleri su sıkıntısı çekmiş olduklarından çeşmelere diğer sulardan su tevzi edilmiştir ${ }^{116}$.

Aşağıda vereceğimiz bir kaç örnek İstanbul'un bazı semtlerindeki acil su ihtiyacını ve nasıl giderileceğini bize en güzel şekilde ifade etmektedir. Başbakanlık Yüksek Makamına takdim edilen 10 Safer 1299 (1 Ocak 1882) tarihli bir mazbatada İstanbul Dolab Deresi'nde beş çeşme ve Taksim civarındaki bir sarnıca gelen su yolları ile Kasım Paşa, Bağhane Deresi, Küçük Cum‘a Pazarı ve civarda ki diğer mahallelerde bulunan ç̧şmelerin su

\footnotetext{
${ }^{112}$ Kanuninin Umumi Kanunnamesi II, Süleymaniye, Aşir Efendi, 1004, vrk. 41a; bk Ahmed Akgündüz, Osmanlı Kanunnameleri ve Hukuki Tahlilleri, 4. kitap, Kanuni Devri Kanunnameleri, I. kısım, Merkezi ve Umumi Kanunnameler, İstanbul 1992, s. 399.

${ }^{113}$ MV. 6, 146, 8 Zilkade 1328 (11.11.1910).

${ }^{114}$ DH.UMVM 57, 73, 18 Rabi 'u'l-ahir 1340 (19.12.1921).

${ }^{115}$ DH.MKT. 15, 1402, 5 Cemaziye'l-ahir 1304 (1.3.1887).

${ }^{116}$ HAT 26783, 542, 29 Zi' lhicce 1233 (30.10.1818).
} 
yollarının tamiri ve tehvini için 3 Safer 1299 (15 Aralık 1881) tarihinde Evkaf-1 Hümayun Nezaret-i Celilesine 150.000 ğuruş vermesi için emir verildiği halde ve hatta aynı emir 7 Safer 1299 (29 Aralık 1881) tarihinde tekrar edilmesine rağmen, para sıkıntısı çekilmiş olacak ki, bu meblağ 1 Evkaf-1 Hümayun Nezareti'nin temin edemediği anlaşılmaktadır. Ancak Dolab Deresi ve sair yerlerde çıkarılan bazı suların yollarının yapılarak çeşmelerden bazılarına gönderilmesi için gerekli para emanet yoluyla (iktida eden akçe suret-i tahvilden ve sa'ireden emvali emanetten verilmiş) temin edilmiş ve muzayaka kısmen giderilmiş olsa da yukarıda zikredilen acil tamiratın gerçekleşmesi gerektiği üzerinde durulmakta ve gerekli paranın Belediye sanduklarından (veznelerinden) derhal temin edilemeyeceği vurgulanmaktadır. Zaten yukarıda adı geçen çeşmelere suyun getirilmesi ve daha önce planlandığı üzere Ayazma Deresi'nden Tophane ve Kılıç Ali civarındaki çeşmelere su gönderilmesi için gerekli meblağın Evkaf Nezareti tarafından verilmesi gerekirdi. Taksim'de su yeterli olmadığından dubalarla getirilen su dahi halkın ihtiyacına kafi gelmemektedir. Dolayısıyla mevcut su sıkıntısının bir an önce giderilmesi için süratle su yollarının tamir edilmesi gerekmektedir. Bunun için işçilerin günlüklerinin (ücretlerinin) ödenmesi yanı sıra 80.000 ğuruşluk boru satın alınması gerekecek. Bu durumda 150.000 ğuruş temin edilemediği takdirde Komisyon çalışmalarına başlayamayacak ve dolayısıyla su sıkıntısı bir kat daha artacağından adı geçen meblağın, Evkaf Nezareti hesabına Maliye Nezareti tarafından verilmesine Sadriazamlıkça müsaade buyrulmuştur ${ }^{117}$. Taksim ve Kasım Paşa gibi semtlerde su ihtiyacı yüksek olduğundan bir çok çareler aranıyordu. Belediye Müdüriyeti'ne yazılan 12 Safer 1299 (3 Ocak 1882) tarihli bir nassa göre Harbiye Okulu'nun (Mekteb-i Fünun-i Harbiye) bahçesinde bulunan bir kuyudan Frenk tulumbası ile Taksim maslağına su gönderilmekte idi ${ }^{118}$. Aynı şekilde 11 Safer 1299 (2 Ocak 882) tarihli bir mazbatadan da anlaşıldığına göre Kasım Paşa taraflarındaki çeşmelere Baruthane Deresi'nden su getirilmiş ve bu su yollarının tamiri için de görevlendirilen Evkaf-1 Hümayun Tamirat Müdürü Nazif Efendi ile üçüncü Daire Belediye Müdürü Sa‘id Beg’e Emanet veznesinden 10.000 ğuruş verilmiştir ${ }^{119}$.

Yukarıda verilen bilgilerden de anlaşılacağı üzere Belgrad karyesindeki su membaları İstanbul için büyük bir önemi haiz idiler. Bu membaların devamlılığının sağlanabilmesi için yağmura ihtiyaç duyulmakta idi. Bunun için de Belgrad ormanlarının muhafazası ve korunması gerekli idi. Dolayısıyla Osmanlı hükümeti bu ormanda ağaç kesimini yasaklamış ve

${ }^{117}$ Vakıflar Genel Müdürlüğü 623 nolu defter, dokuman no: 22.

${ }^{118}$ Vakıflar Genel Müdürlüğü 623 nolu defter, dokuman no: 33.

${ }^{119}$ Vakıflar Genel Müdürlüğü 623 nolu defter, dokuman no: 23. 
Belgrad karyesinde bulunan askeri karakola emir buyurarak bu hususta önlemler almasını istemiştir ${ }^{120}$.

İstanbul'da sular sağlık açısından koruma altına alınır ve gerekli ihtimam gösterilirdi. Bendlerin temiz tutulabilmeleri için buralarda çamaşır yıkanmasına müsaade edilmezdi. Bu konuda dikkatimizi çeken husus Beyoğlu'ndan, hastahanelerden ve bilhassa Efrenc Hastahanesi'nden Belgrad karyesi civarında bulunan Büyük bende arabalarla çamaşır götürülüp yıkandığı ve dolayısıyla suyun nezafetine halel geldiği anlaşılmaktadır. Bunun önüne geçilmesi için Hilafet merkezinden karar çıktığı ve mezkur köyde bulunan askeri karakola emir verilerek buralarda çamaşırhanelerin yapılmasının veya herhangi bir surette çamaşır yıkanmasının önüne geçilmesi istenmiştir ${ }^{121}$.

Sadece İstanbul'da değil Osmanlı'ının tüm şehir ve kasabalarında su yollarının inşasına, bakım ve tamirine, tahlil ve tevziine önem verilirdi. Cami, mescid, medrese, zaviye, han, hamam, sokaktaki çeşme ve sebillere, evlerdeki çeşmelere suyun ulaştırılması konusunda Osmanlı'nın yukarıda izah ettiğimiz gibi son derece iyi organize olduğunu ortaya koymaktadır. Osmanlı Devleti'nin yönettiği her şehir ve kasabada günümüze kadar ulaşan bir çok çeşme ve sebillerin mevcudiyeti ve bir çoğunun hala kullanılmış olması Osmanlı su yolları yönetim ve sisteminin çok sağlam temeller üzerine oturdulduğunun bir göstergesidir.

\section{Kaynakça}

İstanbul Başbakanlık Arşivi,

A.\}MKT.DV.

A.\}MKT.MHM.

A.\}MKT.MV.

A.\}MKT.MVL.

A.\}MKT.NZD

A.\}MKT.UM.

Cevdet Kataloğu, Belediye

Cevdet Kataloğu, İrade Vakıf.

DH.EUM.THR.

DH.KMS.

DH.MKT

DH.TMIK.S.

120 Vakıflar Genel Müdürlüğü 623 nolu defter, dokuman no: 28, 29, 30 ve 32, 11 Safer 1299 (2.1.1882).

121 Vakıflar Genel Müdürlüğü 623 nolu defter, dokuman no: 27 ve 31, 11 Safer 1299 (2.1.1882). 


\author{
DH.UMVM \\ HAT \\ HR.MKT. \\ MD12. \\ MD14. \\ MD19. \\ MD3. \\ MD5. \\ MD6. \\ MD82. \\ Y..PRK.HR.. \\ Y..PRK.MYD. \\ Y..PRK.TKM. \\ Y..PRK.UM. \\ ZB.
}

Vakıflar Genel Müdürlüğü

Vakıflar Genel Müdürlüğü 623 nolu defter

Araștırma ve İncelemeler.

"Fountains in Ottoman Istanbul", http://www.kultur.gov.tr/EN/BelgeGoster.aspx?17A16AE30572D313E603BF9486D43 71DEE5931C025F918AA (erişim 14 Ocak 2008).

"Osmanl1 Başkenti İstanbul'da Çeşmeler" http://www.osar.com/modules.php? name $=$ Encyclopedia\&op=content\&tid=501201\&page=3 (erişim 30 Ekim 2007).

Akgündüz, Ahmed, Osmanlı Kanunnameleri ve Hukuki Tahlilleri, 4. kitap, Kanuni Devri Kanunnameleri, I. kısım, Mekezi ve Umumi Kanunnameler, İstanbul 1992.

Çeçen, M. Kazım, İstanbul'da Osmanlı Devrinde ki Su Tesisleri, İstanbul: İTÜ yayınları 1984.

Çeçen, M. Kazım, İstanbul'un Osmanlı Dönemi Suyolları, İstanbul: İSKİ yayınları 1999 [yeni bask1].

Çelik, Gülfettin, "İstanbul Kaynak Suları (Teşkilat ve İşleyişi ile)”, XIV. Türk Tarih Kongresi (9-13 Eylül 2002), II/I, Ankara 2005.

Göriceli Koçi Bey, Koçi Bey Risalesi, yay. Yılmaz Kurt, Ankara 1994.

Hirsch, Abraham M., "Water Legislation in the Middle East", The American Journal of Comparative Law, Vol. 8, No. 2 (Spring, 1959).

Öziş, Ü.-Türkman, A.-Özdemir, Y., "Historical water Works in Turkey", Ninth International Water Technology Conference, IWTC9 2005.

Pakalın, M. Zeki, Osmanlı Tarih Deyimleri ve Terimleri Sözlüğü, İstanbul 1971.

Sharm El-Sheikh, Egypt: http://www.angelfire.com/pro2/iwtc/2005_pdf/05-1.pdf (erişim 14 Ocak 2008). 


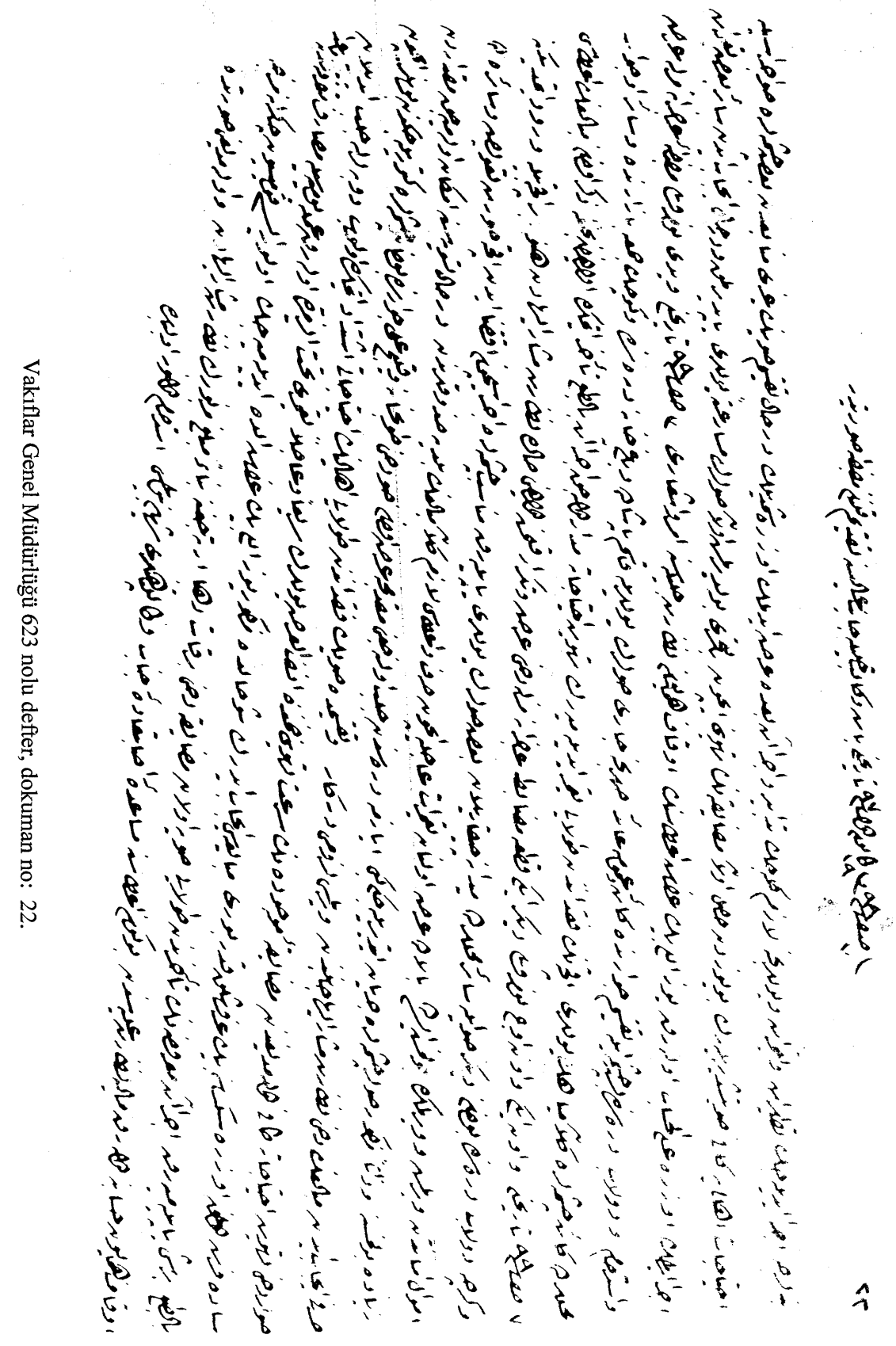




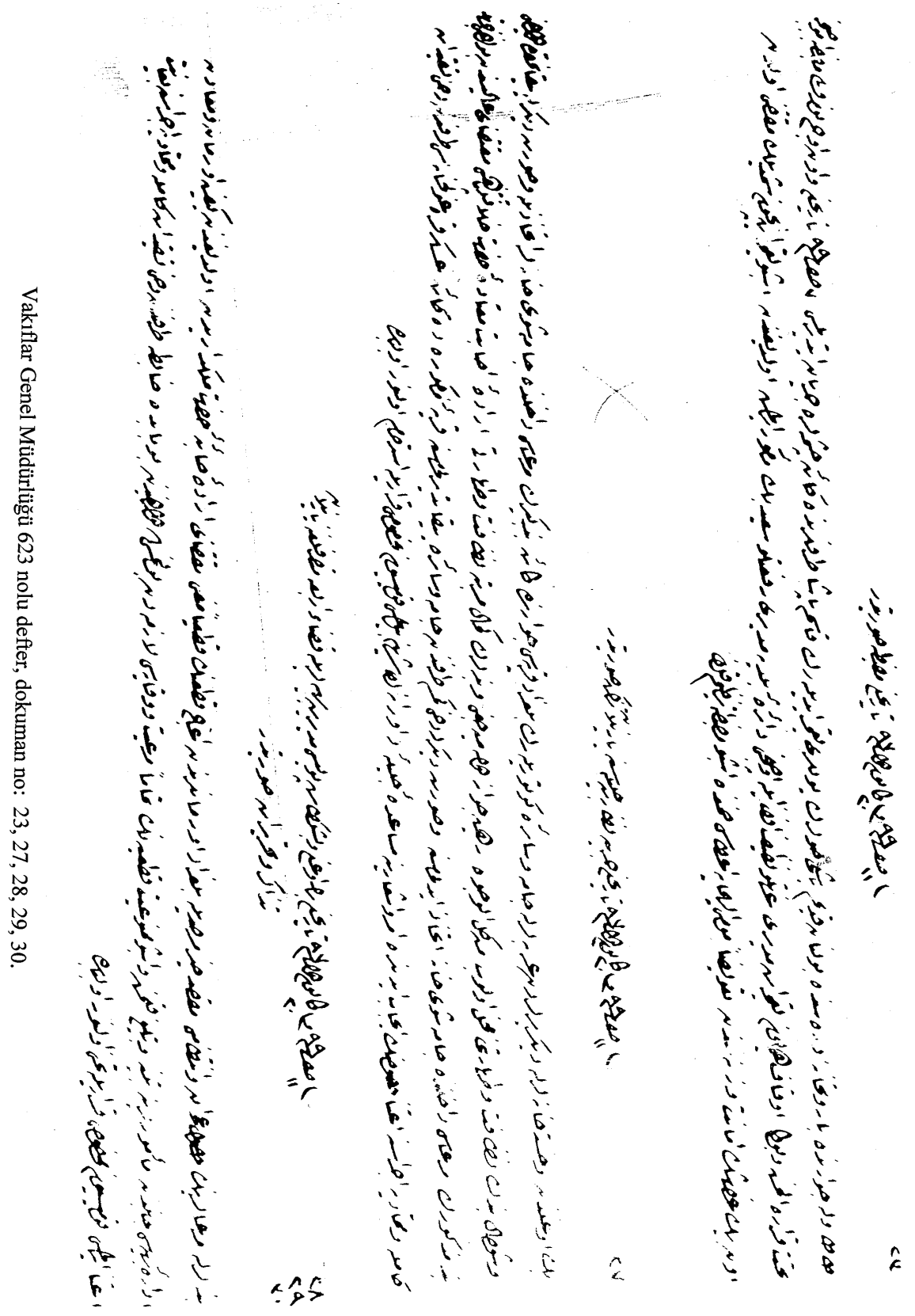




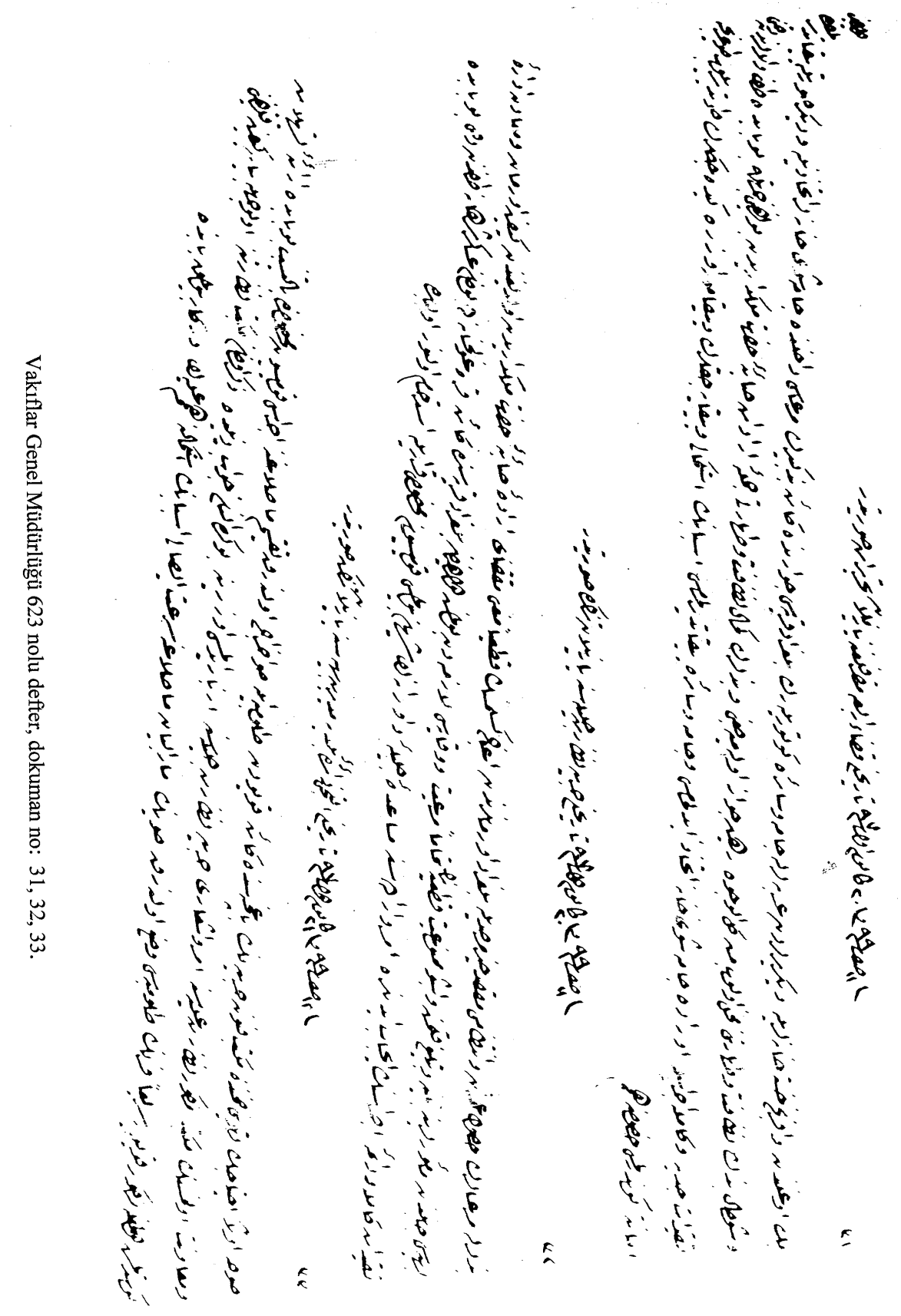

